\title{
MLL/LASP1 Fusion Gene
}

National Cancer Institute

\section{Source}

National Cancer Institute. MLL/LASP1 Fusion Gene. NCI Thesaurus. Code C99335.

A fusion gene that results from a chromosomal translocation $t(11 ; 17)(q 23 ; q 12-21)$ which fuses the $5^{\prime}$ half of the MLL gene to the 3' half of the LASP1 gene. This rearrangement is associated with infant acute myeloid leukemia. 